\title{
Internationalization of higher education: institutions and knowledge diplomacy ${ }^{1, a}$
}

\section{Maria Lígia de Oliveira Barbosa* Clarissa Eckert Baeta Neves**}

\begin{abstract}
The public debate, policy agents and stakeholders, and academic research brought to the center of the debate the issue of internationalization of higher education. Along with questions about what (and how) should be taught, the definition and measure of teaching and learning quality, the equity and diversification of Higher Education Institutions, a discussion emerges as to the meanings of internationalization trends and models in higher education. What does internationalization mean? Are there any measures or methodological parameters to assess it? What institutional models become dominant in the internationalization processes? Did internationalization increase the importance of science for the autonomy of academic institutions? Does knowledge diplomacy effectively contribute to institutional strengthening? Are there global and local policies and strategies for internationalization? How do they work? How do they connect to the democratization of higher education? Which are the main agents in the internationalization processes - are they professors, researchers, staff, students, or other stakeholders? These questions form an entire research program. Some of them are already discussed in the dossier articles. Others are only outlined, indicating new directions for studies in this area.
\end{abstract}

Keywords: internationalization, higher education, institutional models, strategies.

\footnotetext{
${ }^{1}$ Contributions to this dossier were made by different authors throughout 2019, therefore, before the outbreak of corona-virus pandemic. Its publication, however, takes place in the midst of this pandemic with its harsh consequences, and it was only possible thanks to the work of the dedicated professionals of Sociologias' editorial team. Our sincere gratitude to them.

a Translated from Portuguese by Carolina Fernandes

* Federal University of Rio de Janeiro, Rio de Janeiro, RJ, Brazil.

** Federal University of Rio Grande do Sul, Porto Alegre, RS, Brazil.
} 


\section{Internacionalização da educação superior: instituições e diplomacia do conhecimento}

\section{Resumo}

O debate público, os agentes políticos e a pesquisa acadêmica trouxeram para o centro do debate a questão da internacionalização do ensino superior. Juntamente com perguntas sobre o que (e como) se deve ensinar, a definição e a medida da qualidade do ensino e da aprendizagem, a equidade e diversificação nas Instituições de Ensino Superior, emerge a discussão sobre os significados das tendências e modelos de internacionalização no ensino superior. O que significa internacionalização? Existem medidas ou parâmetros metodológicos para avaliá-la? Quais modelos institucionais se tornam dominantes nos processos de internacionalização? A internacionalização aumentou a importância da ciência para a autonomia das instituições acadêmicas? A diplomacia do conhecimento contribui efetivamente para o fortalecimento institucional? Existem políticas e estratégias globais e locais para internacionalização? Como elas funcionam? Como elas se conectam à democratização do ensino superior? Quais são os principais agentes nos processos de internacionalização - são professores, pesquisadores, funcionários, estudantes ou outras partes interessadas? Essas perguntas formam um amplo programa de pesquisa e algumas delas já são discutidas nos artigos deste dossiê. Outras são apenas delineadas, indicando novas direções para estudos nessa área.

Palavras-chave: internacionalização, ensino superior, modelos institucionais, estratégias.

\section{Introduction}

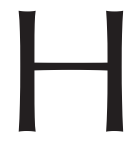
igher education, which for centuries constituted a small and elitist sector in most societies, has become an important institution, in the context of globalization and knowledge society, playing a fundamental role in economic, social, and cultural development.

The recognition of the social and economic importance of higher education has triggered a process of expansion and massification on a 
global scale 2 . Better qualification of human resources has become, more and more, regarded as a key factor of economic competitiveness between countries. At the same time, access to higher education is seen as an important mechanism for reducing inequality of opportunities and as a factor for promoting social mobility. Last, but not least, the production of new scientific, technological and innovation knowledge is a constant challenge posed to Higher Education Institutions (HEls). Altogether these dimensions have allowed for a perspective that analyzes the possible contributions of higher education systems towards increasing social cohesion, mainly by means of strengthening social connections (social capital, in the sense proposed by Robert Putnam) and of the cultural diversity that would take place in the university setting (Marginson, 2016).

Due to the expansion and massification, HEls had their roles multiplied and became complex organizations facing new challenges in the spheres of management, governance, academic administration, education provision, student services, research administration, infrastructure facilities management, financial matters, legal issues and many others. Higher education policy, in this context, has become a field of great social and political interest as well as of debates and disputes. Issues such as access, public support, tuition fees, private sector role, financing policies, research guidance and many other subjects have become topics of debate (Rumbley et al., 2014; Neves et al. 2018). According to Neves, Sampaio and Heringer (2018, p. 20) "it is from this stance of recognition of the importance of higher education that its transformations take place: these are changes in scale and global decentralization of provision, changes in the configuration of supply and, especially, in legitimacy and recognition in contemporary societies".

\footnotetext{
${ }^{2}$ Between 1970 and 2007, the number of higher education students in the world quintuplicated, from 28.6 million to 152.5 million. As of the 2000s, 51.7 million new students were included, most of them from regions of the globe that, until then, had a scant participation in the world's total enrollments in higher education. In 2014 there were 132 million, and in 2018 the number of university students in the world had exceeded two hundred million. These students are concentrated in India (25\%) and in China (32\%). In Africa, less than $10 \%$ of the age group reaches higher education (Altbach; Reisberg, 2018).
} 


\section{Research on the internationalization of higher education}

The sociological reflection on the development of higher education has been advancing together with the changes experienced by the higher education system and the social demands articulated around the meaning to be attributed to tertiary education. In all countries, the higher education systems have been especially confronted with the challenges of democratizing access and improving social equity, as well as with the implications of such challenges for the financing of their operation and growth.

During the 1960s and 1970s, access becomes a central issue, largely due to pressures placed by different social movements, especially black people, women, and students themselves. In the latter decade of the last century, research faces the challenges of massification and, in the 2000s, again under the impact of transparency requirements, higher education systems start to be evaluated also according to their teaching and economic efficiency and, emphatically, according to their ability to offer greater equality of education and social opportunities (Trow, 1970; Gumport, 2007; Gripp; Barbosa, 2014).

More recently, internationalization and excellence have been added to these challenges, two issues that are, in a sense, opposite sides of the same coin. In an increasingly globalized world, where global knowledge networks and systems prevail, universities face the challenge to become internationalized - a no longer merely marginal activity, but a duty of all sectors of the university. As a result, HEls are prompted to reinvent themselves and to provide answers to problems and demands of significant impact. Although, so far internationalization was often an occasional outcome resulting from professors and researchers individual contacts, it has been growing rapidly as HEl's planned actions and as a strategic task of higher education management, with a defined focus on content, methods, people and international structures.

The internationalization of HEls is, more and more, a deliberate process rather than just a passive experience (De Wit et al., 2015). There are huge 
expectations around the internationalized university, its contribution to the globalization process in the 21 st century and its increasingly cross-border ability to compete for the best minds, financial resources, and innovative technologies.

The growing importance of internationalizing higher education is highlighted in 1995, within UNESCO's preparatory document for the World Conference on Higher Education, held in Paris, in 1998:

[t]he growing internationalization of higher education is first and foremost a reflection of the global character of learning and research. This universal context is being reinforced by the current processes of economic and political integration, the growing need for intercultural understanding and the global nature of modern communications, consumer markets, etc. The ever-expanding number of students, teachers and researchers who study, teach, undertake research, live, and communicate in an international context attests to this overall welcome development (UNESCO, 1995, p. 33).

Internationalization of higher education started to be promoted as a strategic factor in the development of HEls, fostered by higher education associations and agencies, through projects and services ${ }^{3}$. Thus, movements for internationalization in higher education start to encourage debate, as well as to influence policies and actions at the system level and in institutional contexts, with a direct impact on academic life.

It is an urgent task, therefore, to reflect on the distinct experiences of internationalization in higher education and analyze the different dimensions, actors, and possible outcomes of this worldwide movement in various regions. To this end, we present this dossier on internationalization of higher education considering its relevance, agents, strategies, trends, and future.

\footnotetext{
${ }^{3}$ In Europe, it is worth mentioning: UNESCO, the European University Association (USA); International Association of Universities (IAU) European Association for International Education (EAIE); Horizon 2020, a European Union (EU) Research and Innovation Program. In the United States: Mapping is a project of the Center for Internationalization and Global Engagement (CIGE) of the American Council on Education (ACE) in its fourth edition. In Latin America: The Regional Conference on Higher Education that, in its third edition held in Córdoba (Argentina), in 2018, had one of its themes centered on the analysis of the internationalization process.
} 
A series of institutional efforts and strategies have been developing since the 1980s. De Wit (2001) describes the historical pathway of practices and meanings of higher education internationalization. In this work, which is his doctoral thesis, De Wit (2001) analyzes the four rationales or possible directions for the main agents of internationalization policies, presenting some of the essential dimensions for a systematic analysis of the process, namely: political (national security, foreign policy, technical assistance, peace and mutual aid), economic (development, competitiveness, labor market), social/ cultural (regional and national identities) and academic (internationalized research and teaching, expansion of the academic horizon, institutionbuilding, improvement of academic quality and standards). By analyzing the difference between approaches of American authors (more focused on activities and competencies, besides the institutional ethos) and European authors (who understand internationalization as a process), De Wit shows how different perspectives are associated with certain historical moments:

[f]rom a historical point of view, 'international education' reflects the period between the Second World War and the end of the Cold War and is more strongly observed in the United States than elsewhere. The 'internationalization of higher education' reflects the period starting with the end of the Cold War, and is more predominant in Europe, as well as Australia and Canada. The differences in meanings accepted by American authors and others for that reason can be explained by the fact that most practice and analysis in the period before the end of the Cold War was done by Americans and still dominates American practice, whereas most practice and analysis of the international dimension of higher education now takes place outside of the United States, in particular Europe, Canada and Australia (De Wit, 2001, p. xi).

From this perspective, properly understanding and conceptualizing the internationalization process requires defining a temporality. The recent study by Gao (2019, p. 35-36) presents an important periodization based on the different characteristics and definitions formulated by researchers and specialists, to understand the changes undergone by universities regarding internationalization. 
In the early 1990s, internationalization was understood as based on programs and activities: it was about the internationalization of HEls through the mobility of teachers and programs. In the mid-1990s and early 2000s, it came to be seen as an ongoing process. By defining periods similarly to De Wit, Gao reaffirms the distinction between American approaches and those developed in Europe, Australia, and Canada. In this period, an outstanding definition of internationalization is proposed by Knight (1994, p. 7): "[t]he process of integrating an international and intercultural dimension into teaching, research and service functions of the institution". Subsequently, internationalization came to be recognized as an institutional approach. From the late 1990s to the mid-2000s, it became a process integrated into all aspects of university life, a university strategy systematically planned and implemented. In view of this, the author updated her definition (Knight, 2004, p. 11) of internationalization: "[t]he process of integrating an international, intercultural or global dimension into the purpose, functions or delivery of post-secondary education".

Thus, a change can be noted in the international dimension of HEls in recent decades. Internationalization, with an emphasis on international cooperation - primarily in research projects, doctorate scholarships and academic mobility of teachers and students - starts to encompass new perspectives. Nowadays HEls are involved in both "at home" and "abroad" internationalization activities. There are increasing expectations that higher education institutions will develop comprehensive internationalization strategies that permeate their whole institutional structure. Internationalization becomes a strategic task for higher education management.

In addition, new dimensions of internationalization have been incorporated by HEls, agencies and stakeholders. Academic mobility has changed from the mobility of students and academics to the mobility of programs and policies. The curriculum is assuming an increasingly international dimension. New information and communication technologies have introduced innovations into distance and online learning, including the recent introduction of mass open online courses (MOOCs) worldwide. 
Universities are establishing campuses in other countries and cities; academic centers are being established and new independent universities are being founded by international partners. Global rankings, knowledge diplomacy, world class universities, franchises, co-diploma programs etc. are other developments of this process (Knight, 2018).

Therefore, it is crucial to understand the reasons, meanings and approaches present in the strategies and organizational models that allow explaining the importance of the subject at the beginning of the 21st century. From the perspective of an institutional manager, De Wit (2001) comparatively analyzes the development of internationalization in the USA and Europe. Thus, the issue of internationalization has a strong appeal in studies of higher education management, as shown in the book by Maringe and Foskett (2012). A study by Craciun (2015) also indicates that the issue has become a critical research question - not only for managers, but also for the social sciences generally - since the internationalization process might bring potential political, socio-cultural, and academic benefits. In this sense, internationalization starts to be perceived as one of the essential drivers of change in higher education systems. Still according to the Hungarian author, studies on the subject have grown, but important gaps remain, particularly regarding adequate conceptualization and measurement of the internationalization process (Craciun, 2015). The dossier proposed here aims to contribute to systematize and advance the discussions, presenting a set of empirical analyzes from different regions of the world for which this issue has been relevant.

Internationalization, as research topic, emerges clearly in close association with the pioneer work of Jane Knight (1994). In a text from 2007, the author produced a framework for a sociological approach to internationalization, establishing lines of research that, until today, guide the best studies. Craciun (2015) indicates the decisive role of the work in this field by authors such as De Wit (2001; Bradenburg and De Wit, 2011), Knight (2007; 2003; 2018; Knight; Lee, 2014) and Teichler (2002; 2009). Considering the whole spectrum of research on this topic, Gao et 
al. (2015) indicate that previously to the rise of this analytical and empirical perspective provided by the social sciences, the research was very broad and general, describing what could be called internationalization. The social sciences make room for more practical work on empirical analysis of the ways in which the process, policies, strategies, actors, practices and disputes or conflicts operate.

Historically, the university appears as an institution that has a universal and comprehensive inclination, considering both the topics and the origin of its teachers and students. However, as of the twentieth century, under the weight of orientations coming from the already well-structured nationstate, a set of internationalization policies and strategies emerges in a very complex, diversified and differentiated historical context, combining the new providers (including commercial ones) of educational services and the formation of transnational networks for the production and distribution of knowledge.

The sociological approach engenders both a concept of internationalization of higher education - distinguishing it from transnationalization, globalization, and even post-internationalization, in De Wit's (2001) terminology- and an empirical study on the meanings socially attributed to the process, the nature of arguments and values mobilized in social disputes, and the strategies and policies institutionally and/or nationally built. The inclusion of empirical research highlights the methodological dimensions that were initially related to the measurement of trends, but which also aimed at identifying agents/actors and organizational and institutional models. Thus, ways were developed to measure both the degree of, more or less active, participation of countries and institutions in formulating and implementing internationalization policies, and the meaning acquired by these policies in disputes over democratization and diversification of the higher education system. At the same time, it is sought to understand which agents or social actors are most proactively involved in this effort into institution building.

A good example is the EAIE Barometer produced by the European Association for International Education (EAIE) to find out the degree of 
internationalization of European HEls. The 2018 Internationalization Report in Europe resulted from a survey that interviewed 2,317 professionals involved in internationalization, from 1,292 HEls in 45 countries (Sandström; Hudson, 2018). The results point to some similarities when it comes to the approaches adopted by European HEls regarding internationalization: for example, more than half of them have Internationalization Offices responsible for planning internationalization.

The main objectives of internationalization that emerged were as follows: preparing students for the global world (76\%), improving the quality of education (65\%), institutional reputation/competitiveness (53\%), improving the quality of research (38\%), financial benefits $(12 \%)$, better service to the local community (11\%), responding to demographic changes $(8 \%)$, others ( $2 \%)$. Among the problems and challenges pointed out there were: insufficient internal budget; lack of commitment from some employees; lack of internal recognition; lack of international scholarships; lack of students/staff trained in foreign languages; lack of institutional structure and leadership; lack of team expertise; students are not looking for international education; lack of integration of international students; lack of mastery of the local language by the student/international team.

In total, $81 \%$ of the surveyed HEls reported that they consider the future of internationalization to be positive or very positive, while only $4 \%$ were skeptical. These optimistic figures provide evidence that individuals working on internationalization in higher education institutions in the European Higher Education Area/EHEA have a more positive view and believe in the future of the field (Sandström; Hudson, 2018, p. 46).

Another survey worth mentioning is the Global Survey on Internationalization of Higher Education, conducted by the International Association of Universities (IAU), since 2003. In 2018, the 5th IAU Global Survey was carried out with the participation of 907 higher education institutions from 126 countries. The research sought to investigate the HEI's strategies for internationalization (Marinoni, 2018). The report covers a wide variety of aspects of internationalization: its importance; its perceived benefits 
and risks; obstacles; internationalization of research; standards and goals for institutional mobility; issues related to curriculum changes and learning outcomes; and support infrastructures implemented by the institutions. The results showed that most HEls (about 89\%) developed internationalization policies and strategies and have an office or team dedicated to implementing and monitoring policies and strategies (Marinoni, 2018).

These are two comprehensive surveys whose results deserve further discussion. They are, per se, an indication of both the relevance of the subject and the similarity and contemporaneity of local processes - possibly associated with the intense collaboration between institutional managers worldwide and with the wider dissemination of efforts and policies aimed at internationalizing higher education.

The verification of the growing strength of internationalization processes in all continents, though most prominently in Europe, has required from state and institutional managers a very fine-tuned and careful focus on the quality and the more purely academic purpose of actions, strategies and policies towards internationalizing higher education. The strength of this appeal is greater when one considers the challenges posed to the foundations of the Western university model (freedom of thought and expression, democracy and civil rights) due to the emergence of nationalist, religious and antidemocratic rhetoric in several countries (Sandström; Hudson, 2018).

Considering the advances and the exuberance of the work of university leaders, and building on the critical disputes prompted by educational research, the dossier proposes a social sciences approach, aimed to analytically understand internationalization trends that, according to different geographical regions, combine distinct social agents in the production of reasonably varied policies and processes. It should be noted that emphasis was placed on the regional dimension due to its centrality to the concept of internationalization and to the associated institutional processes.

\section{Internationalization of higher education: institutions and knowledge diplomacy}


By reading journals specialized in higher education and aimed at a clearly defined audience such as institutional leaders and researchers on the topic, one can note some nuances in the approach to internationalization. In the International Higher Education's commemorative edition of the 25th anniversary of the Boston College Center for International Higher Education, two editors of the journal, De Wit and Altbach (2020), mention the unprecedented challenges faced by universities worldwide. The editors specially highlight the fact - aggravated in these 25 years - that American universities are abdicating their leadership in the realm of internationalization. Even though the number of international students has doubled in this period (from 450,000 to one million) and the economic return of the sector has gone from 7 to 40 billion dollars, the American presence in international student mobility and the number of American institutions at the top of the rankings have been dropping significantly. Apparently, the decline in the American presence would be connected to the surge of nationalism and populism that hit the world and the country itself. And, if the numerical outcomes are not so bad, they are associated with changes in curricular structures and in the distribution of students over academic disciplines, which happen to the detriment of the humanities, and of the knowledge of other languages and other cultures. The cultural dimension of internationalization is, thus, weakened.

This approach highlights the distinct dynamic of internationalization, which is very diverse depending on the agent's position as either provider or host of institutions, on the country being importer or exporter of students, professors, researchers, or being a central or peripheral country within the knowledge and technology production networks. These variations depend on each country's geography and history, as well as on other dimensions of globalization. The development of a knowledge diplomacy (Knight, 2020), capable of managing increasingly internationalized complex situations (from the environment to epidemics, including refugee issues) brings to attention the analysis of the conditions of scientific production, one of the guiding lines of internationalization policies. 
Trying to grasp both regional variations in the internationalization of higher education and the possibilities of scientific production, the dossier brings different perspectives, always seeking comparative analyzes that highlight Brazil's entrance into this complex network. In this context, the first article, entitled Challenges for research in higher education: the case of internationalization between the explanandum and the explanans, by Amélia Veiga and Antônio Magalhães, examines the injunctions between scientific research guided by the theoretical framework of the disciplines, and the requirements of the political agenda and coordination. Observing the case of research on higher education in Europe stirred by the winds of Brexit, the authors identify in the research discursive elements that reify both the notion of State and that of higher education: "[b]y focusing on the Brexit momentum that brought to the front stage the centrality of the nation-states and their competition/cooperation relationship, this paper contributes to call into attention the epistemological and methodological implications of isms." By highlighting the relationship between the State and the notions and operation of higher education, the article makes room for debates on the meaning and values ascribed to universities and research in Brazil, particularly for the study of internationalization policies, a subject that still receives scant attention in the country. The political moment has left difficult marks in the ministries of education and foreign affairs and may encourage a critical assessment of the sustainability of institutional internationalization policies. It would also be important to investigate how nationalisms across different political parties in the political spectrum can (or not) intervene on the conceptual and methodological structure of research on higher education and on Brazilian participation in the global scientific-technological development.

The next article, entitled University, science and the new (and old) academic roles: inner sources of institutional resilience, by Elizabeth Balbachevsky and Vuokko Kohtamäki, examines the transformations in university governance associated with internationalization, focusing on the decisive role of the interplay between institutional and scientific norms in 
university's resilience and autonomy. The authors compare the University of São Paulo and the University of Tampere, in Finland, showing how much the university can preserve its identity as part of the republic of science by resisting the purely managerialist logic of some reforms. This means that the university preserves itself as an autonomous institution by nesting science and its operating logic based on disciplinary guidelines. Obviously, it is an institutional autonomy that goes far beyond the financing conditions so often mentioned in debates on the subject. And the comparison with a Brazilian institution indicates the persistence of this institutional value in social and historically quite different contexts. In addition, a redesign of the academic profession appears as a common feature in both countries, where the individualistic professor loses ground so that to make room for more collective, departmental, or programmatic work, in the case of more internationalized institutions. This would be an excellent research strand on the academic profession: a fundamental agent in the construction of the university autonomy that suffers the impacts of organizational transformation linked to internationalization.

In the article Política exterior y procesos de internacionalización del sistema científico y universitario. Argentina y Brasil 2003-2019 (Foreign policy and processes of internationalization of the scientific and university system. Argentina and Brazil 2003-2019), Andrés Santos Sharpe and Daniela Perrota examine the internationalization of higher education in the foreign policy context of the two largest countries in South America, Argentina and Brazil, both members of Mercosur. They seek to understand the paths chosen for internationalization of science and the university and the institutional mechanisms used by each country to this end. In the conclusion, the authors highlight the, perhaps excessive, centrality of academic mobility programs, even when forming research networks and increasing joint publications. They also indicate that, despite the beginning of processes for title recognition, too little has been done at home in terms of internationalization in the two countries and of discussion of curricula. The difficulty of accessing 
information about the processes in question can also be an indicator of the scant attention received.

With a different approach, the text Higher education internationalization: excellence or networks? What do BRICS-countries need most? by Maxim Khomyakov, Tom Dwyer and Wivian Weller focuses on creating horizontally structured networks, taking as an example the University proposed by the BRICS countries. According to the authors, "while excellence projects do help to develop world-class education, the networks better answer current needs of the BRICS countries". Dealing with the multiple dimensions of globalization, which among other imprints attaches an important commercial character to higher education institutions, the article shows that the institutions of the so-called Global South are constrained to two types of strategies: seeking their place in the fierce global competition for excellence or building an alternative version. This is described as the creation of horizontal networks. The authors conclude with the expectation/hope that building this type of institution will strengthen the normative dimension in a group of countries characterized by extreme pragmatism.

This is, of course, a difficult bet. Considering the article by Andrés Sharpe and Daniela Perrota, which points out the struggles of internationalization policies, and including the next text, by Clarissa Baeta Neves and Maria Ligia Barbosa, one can ask to what extent institutional or even historical-social conditions would exist for accomplishing such a project. The mentioned pragmatism is a thread that leads to several commercial and economic conflicts, in addition to the deep cultural differences between the countries belonging to the BRICS bloc. It is also important to mention that the quality of institutions traditionally well placed in international rankings is a factor that moves universities towards internationalization, with quality improvement being one of the main institutional objectives in this process. An important aspect is the mobility of BRICS students towards the best institutions in the traditional rankings. It would be important to verify to what extent this horizontal network would have the capacity to mobilize students from each country, as well as teachers and researchers. 
The next article, by Clarissa Baeta Neves and Maria Ligia Barbosa, Internationalization of higher education in Brazil: advances, obstacles, and challenges, aims to analyze the experience of HEls and development agencies in Brazil regarding the internationalization phenomenon. The authors present a summarized account of the main features of higher education and postgraduate system in Brazil, examining the cooperation and international influences, as well as the internationalization policies carried out by the central government agencies and by the HEls themselves through institutional initiatives. The authors note a still incipient internationalization of the Brazilian higher education system and that the HEls have been scarcely proactive in the development of internal policies for receiving and seizing the opportunities open up in the process. In line with the results of the analysis by Andrés Sharpe and Daniela Perrota, the authors claim that internationalization activities are concentrated in some graduate programs of excellence and are still deeply reliant on the promotion of government agencies. Brazilian institutions have devoted little effort to encourage the coming of international students and are poorly prepared for receiving those who come. There are also difficulties in hiring or lack of resources for inviting foreign professors and researchers.

In short, the scenario of the Brazilian situation, despite the usual exceptions mentioned in the articles, is one of scarce active integration into the internationalization processes. This passivity demands an actively steered work of institutional construction and information - perhaps by scientific promotion agencies themselves - in addition to creating forms of controlling the international actions aimed at providing institutions and courses, in progress in the country. The characterization of this new situation in the internationalization processes is presented in the text by Jane Knight, that closes this dossier.

Jane Knight's article, The internationalization of higher education scrutinized: international program and provider mobility, presents a reflection on the highly diversified modes of internationalization in most recent times. Counterbalancing between advantages and risks, Knight proposes a typology 
to advance in the analysis of current phenomena such as the International Mobility of Providers and Programs (IPPM) and the revolution brought forth by the technological advances that generated Mass Open Online Courses (MOOCs). The proposed typology is based on two principles: the nature of the relationship between provider and host higher education institutions, and the mode of delivery of the service. Using a typology comprising six categories that allow classifying some experiences worldwide, the author highlights the Latin American countries in which foreign institutions have installed campuses associated with the original university. Like the other authors participating in this dossier, Jane Knight shows the difficulty in obtaining reliable data on the subject. The elaboration of a typology would aim to ease and systematize the data production by the States and national institutions. Among the types of action analyzed, international partnerships and collaborations offer the most optimistic picture. These refer to joint universities, with the participation of different countries and the creation of distance education programs with local partners. However, the text also allows a glimpse of less positive aspects, as the possibility of offering courses of low quality or inadequate to local needs. It also alerts for the risks of excessive commercialization and the difficulties in recognizing certification and equivalence of curricula.

The final part of the text includes a robust research program, specifically aimed at the growth of IPPM in various countries, structuring the new internationalization modalities. With that, we can draw some conclusions that forecast research strands particularly relevant in the Brazilian and Latin American contexts.

\section{Research paths}

The variety of issues and themes addressed in this dossier allows for a critical analysis of the social dynamics that organize higher education systems virtually worldwide. The list can start with the conceptual and methodological issues. The policies on internationalization of higher education mean different 
things to different actors or in different contexts. Although this presentation seeks to advance a comprehensive concept of internationalization, there is no intent to exhaust all conceptual alternatives. Criticisms often arose regarding the development of internationalization as a weapon for imposing the values of neoliberalism or for the commercialization of education (Lima; Contel, 2011) or to favor both the dominance of the English language and the traditional university model (Marginson, 2007). A study that goes further - both conceptually and methodologically - building a definition of internationalization capable of specifying social, institutional, political, economic, and cultural features of the current models and their alternatives would be important. The article proposing the creation of networked institutions among the BRICS, as opposed to universities historically at the top of international classifications, could be a first step in this direction.

More than that: Brazil has an excellent educational data collection system (INEP - National Institute of Educational Studies and Research Anísio Teixeira), which deserves more in-depth attention from researchers to establish forms of scientific collaboration that produce adequate information for this type of research. In other countries, in addition to international organizations, authorities and researchers can act in the same direction. Some of the struggles faced by higher education researchers are associated either with the lack of adequate data or with difficulties to access existing data. The easy access to data would allow researchers to elaborate measures and to specify dimensions of the internationalization processes, refining concepts and analysis. The methodological advances would strengthen the different research strands mentioned in the texts of this dossier, especially that by Jane Knight, strongly focused on conceptual advancement.

The issue of relations between university, internationalization, science, and the State covers almost the entire dossier. Somehow, each of the texts touched these points. The analyzed processes allow us to question the extent to which these institutions around the world, which are involved in a fierce competition for spaces on the global stage, share the same identity (Yonezawa, 2020). In other words, what model of university is 
internationalized? How can science and the academic profession define characteristics of internationalized universities? What kind of more or less democratic configuration of political values does facilitate or hinder the development of internationalization? Understanding the diplomacy of science requires a deeper analysis of the functioning of institutions in various national contexts and different fields of knowledge, a specification of the actors involved and of available resources and an assessment of the ways of implementing internationalization policies, particularly in their collaborative forms. The reflection initiated in the texts of Elizabeth Balbachevsky and Vuokko Kohtamäki, and of Andrés Sharpe and Daniela Perrota deals with various dimensions of diplomacy of knowledge and, at least regarding this, the need for partnerships between social sciences researchers and those studying management and governance of institutions and the university system becomes evident.

In a moment of a most serious crisis generated by COVID-19, international collaboration in scientific research transcends traditional university settings and enters the public sphere and the political debate, thus attaining a more robust and more widely shared social value. This offers a huge opportunity for scientific research to gain legitimacy. At the same time, science becomes a political argument, mobilized especially against the narrowness of uninformed opinions, prejudices and the bad faith of populist political actions. Thus, its social importance increases as it is produced in the best models. Nevertheless, ignorance and hatred also grow stronger. The resumption of normal life will be problematic in the economic sphere and, probably, quite difficult for current university institutions, which should review practices and models, seeking also to strengthen themselves through decisions and policies more strongly oriented towards their own internationalization.

Finally, from the analysis of advances and difficulties of internationalization in Latin American countries, a question remains regarding the actors and protagonists/stakeholders of this process: who are these actors? Managers? The academic profession? The politicians? Or, more likely, different 
combinations of groups of actors? The answers to these questions permeate all subjects approached in this dossier. They encompass studies on science and professions, on identity and institutional policy, reaching national policy and social values.

Anyway, particularly in the case of countries with scant internationalization, or with little active participation in the process, perhaps the most important first step is to produce a debate that allows different actors to explain the reasons, risks and benefits of the internationalization of higher education. Thus, it is about convincing different individual and institutional actors that the process tends to be inexorable in the contemporary world but it can and must be internally controlled to ensure more benefits, higher quality and less commercialization for the internationalization of the national system.

Maria Ligia de Oliveira Barbosa is associate professor at the Federal University of Rio de Janeiro (UFRJ) and leader of LAPES (Higher Education Research Lab/UFRJ/CNPq), Rio de Janeiro, RJ, Brazil.

$\bowtie$ mligiaifcs@gmail.com

Clarissa Eckert Baeta Neves is full professor at the Federal University Rio Grande do Sul (UFRGS) in the Graduate Program in Sociology, a CNPq 1a researcher and leader of GEU/ UFRGS the Group of Studies on Universities.

\ clarissa.neves@yahoo.com.br

\section{References}

1. ALTBACH, Philip G.; REISBERG, Liz. Global trends and future uncertainties, Change: The Magazine of Higher Learning, v. 50, n. 3-4, p. 63-67, 2018. https:// doi.org/10.1080/00091383.2018.1509601.

2. BRADENBURG, Uwe; DE WIT, Hans. The end of internationalization. International Higher Education, n. 62, 2011. https://doi.org/10.6017/ ihe.2011.62.8533

3. CRACIUN, Daniela. Systematizing internationalization policy in higher education: towards a typology, Perspectives of Innovations, Economics and Business, v. 15, n. 1, p. 49-56, 2015. http://dx.doi.org/10.15208/pieb 
4. DE WIT, Hans. Internationalization of higher education in the United States of America and Europe. Thesis (PhD in Humanities). University of Amsterdam, 2001. Available at: https://dare.uva.nl/search?identifier $=7$ f8def8d-699c-4812ac69-0ab486926488

5. DE WIT, Hans; ALTBACH, Phillip: Unprecedent challenges, significant possibilities. International Higher Education, v. 100, p. 3, winter 2020.

6. DE WIT, Hans; HUNTER, Fiona; HOWARD, Laura; EGRON-POLACK, Eva. The internationalisation of higher education, Brussels, European Parliament, Committee on Culture and Education, 2015.

7. GAO, Catherine Y. Measuring university internationalization: indicator across national contexts. Melbourne: Palgrave MacMillan, 2019.

8. GRIPP, Glicia S.; BARBOSA, Maria Ligia O. A sociologia da educação superior: ensaio de mapeamento do campo. In: BARBOSA, Maria Ligia O. (org.). Ensino superior: expansão e democratização, v. 1. Rio de Janeiro: 7Letras, 2014. p. 19-49.

9. GUMPORT, Patricia J. (Ed.). Sociology of higher education. Baltimore: The Johns Hopkins University Press, 2007.

10. KNIGHT, Jane. Internationalization: elements and checkpoints. CBIE Research, n. 7, 1994. Available at: https://files.eric.ed.gov/fulltext/ED549823.pdf

11. KNIGHT, Jane. Internationalization of higher education practices and priorities: IAU Survey Report. Paris: International Association of Universities, 2003.

12. KNIGHT, Jane. Internationalization remodeled: definition, approaches, and rationales. Journal of Studies in International Education, v. 8, n. 1, p. 5-31, 2004. https://doi.org/10.1177/1028315303260832

13. KNIGHT, Jane. Internationalization: concepts, complexities, and challenges. In: FOREST, James J. F.; ALTBACH, Philip G. (eds). International handbook of higher education, v. 18 Dordrecht: Springer, 2007.

14. KNIGHT, Jane. The international university: models and muddles. In: BARNETT, Ronald; PETERS, Michael A. (ed.). The idea of the university: contemporary perspectives. New York: Peter Lang Publishing, 2018.

15. KNIGHT, Jane. Knowledge diplomacy: what are the key characteristics? International Higher Education, v. 100, p. 38, winter 2020.

16. KNIGHT, Jane; LEE, Jack. An analytical framework for educational hubs. In: KNIGHT, Jane (Ed.). International education hubs: student, talent, knowledgeinnovation. Dordrecht: Springer, 2014. p. 29-42

17. LIMA, Manolita C.; CONTEL, Fabio B. Internacionalização da educação superior: nações ativas, nações passivas e a geopolítica do conhecimento. São Paulo: Alameda Casa Editorial, 2011. 
18. MARGINSON, Simon. The public/private divide in higher education: a global revision. Higher Education, v. 53, n. 3, p. 307-333, 2007. https://doi.org/10.1007/ s10734-005-8230-y

19. MARGINSON, Simon. Higher education and the common good. Melbourne: Melbourne University Press, 2016.

20. MARINGE, Felix; FOSKETT, Nick. Globalization and internationalization in higher education: theoretical, strategic and management perspectives. London and New York: Continuum, 2012.

21. MARINONI, Giorgio. Internationalization of higher education: an evolving landscape, locally and globally. IAU 5th Global Survey. DUZ Medienhaus; International Association of Universities, 2018.

22. NEVES, Clarissa B.; SAMPAIO, Helena; HERINGER, Rosana. A institucionalização da pesquisa sobre ensino superior no Brasil. Revista Brasileira de Sociologia, v. 6, n. 12, 2018. http://dx.doi.org/10.20336/rbs.243

23. RUMBLEY, Laura E. et al. Higher education: a worldwide inventory of research centers, academic programs, and journals and publications. 3. ed. Bonn: Lemmens, 2014.

24. SANDSTRÖM, Anna-Malin; HUDSON Ross. The EAIE Barometer: internationalisation in Europe (second edition). Amsterdam: The European Association for International Education (EAIE), 2018.

25. TEICHLER, Ulrich. Internationalisierung der hochschulen: vergleichende perspektiven und deutsche erfahrungen. Das Hochschulwesen, v. 50, n. 1, p. 3-9, 2002.

26. TEICHLER, Ulrich. Internationalization of higher education: European experiences. Asia Pacific Education Review, v. 10, p. 93-106, 2009.

27. TROW, Martin. Reflections on the transition from mass to universal higher education. Daedalus, v. 99, n. 1, p. 1-42, 1970. https://www.jstor.org/ stable/20023931

28. UNESCO - United Nations Educational, Scientific and Cultural Organization. Policy paper for change and development in higher education. Paris: UNESCO, 1995. Available at: https://unesdoc.unesco.org/ark:/48223/pf0000098992.

29. YONEZAWA, Akiyoshi. Do we share a common university identity? International Higher Education, v. 100, p. 4, winter 2020. 
Received: 27 Apr., 2020. Approved: 10 May, 2020. 
